Swarthmore College

Works

Fall 2016

\title{
Introduction To Part 2 Of A Symposium On Teachers As Leaders: Teachers Write Now: Collaborating, Writing, And Acting On Teacher Leadership
}

Lisa Smulyan , '76

Swarthmore College, Ismulya1@swarthmore.edu

Follow this and additional works at: https://works.swarthmore.edu/fac-education

Part of the Education Commons

\section{Recommended Citation}

Lisa Smulyan, '76. (2016). "Introduction To Part 2 Of A Symposium On Teachers As Leaders: Teachers Write Now: Collaborating, Writing, And Acting On Teacher Leadership". Schools: Studies In Education. Volume 13, Issue 2. 198-210. DOI: 10.1086/688522

https://works.swarthmore.edu/fac-education/112

This work is brought to you for free by Swarthmore College Libraries' Works. It has been accepted for inclusion in Educational Studies Faculty Works by an authorized administrator of Works. For more information, please contact myworks@swarthmore.edu. 


\title{
Introduction to Part 2 of a Symposium on Teachers as Leaders
}

\author{
Teachers Write Now: Collaborating, Writing, \\ and Acting on Teacher Leadership
}

\author{
LISA SMULYAN \\ Swarthmore College
}

Being a teacher leader often means that I am saying "yes" to everything. Every meeting, every panel, every opportunity to network or plan. I have a responsibility to represent teachers and to raise a teacher voice. It's a reaction to the way in which teacher's work has been so circumscribed, how teachers are so hemmed in by the walls of their classrooms, isolated from the rest of the world, and anchored down by heavy workloads and lack of time. In my vision of the profession, teachers do work outside their classrooms, connected to policymakers and community organizations, sharing realities from the heart of education - the classroom. They have time to write and reflect, share and connect. Even though this vision is far from the reality right now, I try to live it as much as I can, to make the road by walking.

-Kathleen Melville, Workshop School English and Spanish teacher

(March 2014)

A teacher who sees themselves as a teacher-leader has a unique view that is both deeply local and broadly political. Teachers are with children every day, doing the work, and learning and growth happen so very locally, in each relationship between teacher and student or amongst students, and so very incrementally, action and reaction, shifts in understanding and ability day to day. But teachers with this leadership stance, while holding themselves accountable for the important local, incremental work of educating each child, still keep a bigger picture in mind. They are aware of the impacts

Schools: Studies in Education, vol. 13, no. 2 (Fall 2016).

(C) 2016 by Francis W. Parker School, Chicago. All rights reserved. 1550-1175/2016/1302-0002\$10.00

198 
of institutional decisions not only on their own work, but on the work of their colleagues. They consider not just what is best for each particular student, but what promotes equity across the class, across the school, across the system. They consider not only how to overcome the impediments to their practice - tired or hungry students, lack of funds for classroom materials - but how these impediments are the products of an inequitable system, and then they advocate for changes to that system. They consider how the learning that happens in second-grade morning meeting or in eleventh-grade English may impact who their students become and what kind of change they, in turn, enact in the world. In other words, teachers with a teacher leader stance pour their hearts and souls into their students, but they don't lose sight of the context.

- Jennifer Lunstead, Wissahickon Charter School, second-grade teacher and lower school head (March 2014)

For the past 5 years I have been working with $\mathrm{K}-12$ teachers, including Kathleen Melville and Jennifer Lunstead, exploring the concept of teacher leadership. A 2011 grant from the Ford Foundation allowed 5 college professors and $16 \mathrm{~K}-12$ teachers to gather for two summers and occasional school-year meetings to talk, to learn from one another, to write about and to practice the many ways in which teachers lead in their classrooms, their schools, and their districts. A second grant from Swarthmore College supported a Philadelphia teacher group-Teachers Write Now (TWN) - in continuing the conversation. As I describe in the introduction to the first part of the Schools symposium on teacher leadership (Smulyan 2016), these discussions led us to a new way of understanding and acting upon the idea of teacher leadership:

Eventually, teacher participants began to explain that teacher leadership was not just about what they did; it wasn't just a set of skills or behaviors that they could learn or teach to others. Teachers . . . say that they have come to see teacher leadership as a stance, a way of being a teacher, that coalesces around being a professional, an intellectual, a fierce advocate for students and colleagues who ensures that everyone has the opportunity to learn and grow, and a collaborative member of a community dedicated to civic and social justice. They argue that no one could have taught them this stance; it developed through a process of interaction with others who shared their questions, their concerns, and their commitments. (Smulyan 2016, 16-17) 
While the first part of this symposium examined teachers' development of this teacher leadership stance, this second installment explores in more detail our use of teacher writing as part of teacher leadership.

The work represented in both parts of this symposium began several years ago as a book project. During a breakout session in the second teacher leadership institute funded by the Ford Foundation (Consortium for Excellence in Teacher Eduction [CETE] Teacher Leadership for Urban Schools, held in the summers of 2011 and 2012), a group of teachers and I gathered to talk about "What Next?" - or how the cohort of 16 teachers who had met for two summers and several during-the-year sessions could continue their work together. The group animatedly discussed the inherent value of being together and the need for the group to find ways to continue to meet. The participants also noted the importance of teachers entering into the discourse about teaching and teachers that they saw as dominated by organizations like Teach For America. They noted: "We want to challenge this discourse, presenting an alternative narrative about who teachers are, why they teach, what they need in order to develop as teachers and teacher leaders, and why it matters that they do develop in these ways over time and stay in the classrooms" (Field notes, July 2012). We thought that a book, written by teachers in the institute, could contribute to this alternative narrative.

Our conversations about this book project continued in this group and, more regularly, in the spinoff group, Teachers Write Now, that I organized in Philadelphia in the fall of 2012 as a way of continuing and extending the work of the Ford Foundation cohort. We brainstormed structures, frameworks, titles, and content. The teachers ultimately decided that I needed to provide the framework and introduction for this book; they felt that they did not have the time or expertise to develop a book proposal, and they wanted me to push the project forward. But it was always clear that their writing would be the center, and primary content, of the book.

When I took the book proposal to a major education publisher in the spring of 2014, I was told that there were a lot of books on the market right now about teacher leadership. It did not look, to the acquisitions editor I talked to, that we had "anything new to contribute to the conversation." She suggested that if perhaps we had some big name educator involved in the project, it might be marketable but that a book consisting of chapters each written by a teacher would not interest the press. Eventually we connected with Schools in order to continue with the project in a way that felt true to our initial goals.

Three key issues stand out for me in this story. First, these teachers have remained dedicated to finding time to come together. While they valued the 
teacher leadership workshops provided in the first several years, they talked more about the time they spent together coming to know one another as passionate professionals. Second, I continue to be impressed by the teachers' commitment to writing. When I taught public school, it never occurred to me to write about my experience or to share my views about teaching with a larger community. These teacher leaders, however, see writing as an important way to organize their ideas, share them with others, and to be part of the educational and political processes that impact their lives and their ability to teach. Third, given the teachers' own commitment to raising and sharing their voices, I was surprised by the acquisition editor's comments that we had nothing new to say, no important (or at least marketable) voice to add to the conversation. Teacher writing, including the writing in this symposium, allows teachers to engage in the professional, collaborative, and political work of teaching. Teachers are the small names in the system of education, not the big name required by the publisher. But our work suggests that these teacher leaders are those to whom the rest of us should turn to learn about teachers, policies, teaching, and learning.

My work with Teachers Write Now stands as an example of these three themes. TWN began in the fall of 2012 with a group of teachers from the Philadelphia area, some of whom had been part of the two-year Ford Foundation teacher leadership cohort. The five Philadelphia area teachers in the Ford Foundation cohort and I agreed that they would each invite a colleague to join us in order to increase the group size and expand the community of teacher leaders with whom we could work. We began meeting once a month that fall with nine teachers, and we have continued to meet monthly since then. Our work has ranged from check-ins to writing retreats, to serving as an emotional and political support group, to using a problem of practice protocol as a consultancy group. In the rest of this piece, I explore the development of this group over time as an example of a community of teacher leaders who have chosen to meet, to write, and to act on their personal and political commitments to teaching.

\section{Collaborating into Leadership}

The teachers in TWN regularly talk about the importance of our group meetings as a place where they can share, explore, and problem solve the professional challenges they face. Through these conversations, they discover insights, hear new ideas, and feel legitimized as teachers who have important things to say to their colleagues, their schools, and the larger communities within which they work. At a meeting early in our first fall, for example, 
teachers wrote about their goals for the year. I suggested that each of them should focus both broadly and specifically on a possible project, one that students in a class I was teaching in the spring might be able to support.

Stacey Carlough, an English teacher, focused on her continuing work as the founder and head of the Writing Center at her charter high school:

My questions revolve around the Writing Center-Does it work? How does it work? Why does it work? What aspects of my school culture and school setting enable it to work? For whom does it work? How does having student tutors enrich the work we do? What does it offer those tutors themselves? This is something I think is unique and fully worth investigating. I obviously see the need for quantitative data and want to get better at crunching those numbers and looking for correlating data on student growth, but I am far more interested in the nuanced, qualitative data that can be gathered via vignettes and experiences and personal growth - the Writing Center, I believe, teaches habits of mind, collaboration, humility, and those are qualities that students need to hone in addition to grammar and punctuation.

My questions about the Writing Center come from people encouraging me to validate the good work I'm doing, to share it, to create models for other school to replicate. My hesitation in doing so has come in part from my own, "Well, it isn't really that special," and my odd lack of ownership slash proprietary love for this project. (TWN writing, November 2012)

Over the course of the first year, 2012-13, Stacey used a Swarthmore student researcher to interview students, teachers, and administrators in her school, trying to find out more about how and why the Writing Center worked. She used her findings to improve the work of the center and to continue to build a more collaborative culture within her school (see Carlough [2016]).

During that first year, the group also had conversations about themselves, their work, and the general environment of teaching both in Philadelphia and more broadly. Kathleen Melville's wrenching story of how her principal attacked her voluntary work on the student newspaper led us to talk about what students learn from out-of-classroom work and how administrator actions can so badly bruise teachers who are active and engaged. This led to a more general conversation about the role(s) of principals in supporting, but much more often undermining, teachers and teacher leadership. What did it mean when Maeve O'Hara Siu, a math teacher at a public high school in

202 Schools, Fall 2016 
Philadelphia, said about her principal, "She's better than most," or when the best thing a teacher could say about a principal was, "He's hands off, better than most"? We also read and discussed an article I brought in on teacher leadership by two people (one of whom was a job candidate at Swarthmore) whose experiences came through Teach For America and the charter schools (e.g., Kipp [a nonprofit network of college-preparatory, public charter schools serving elementary, middle, and high school students]) often served by Teach For America. I was looking for feedback on the candidate and could not figure out exactly why I was not completely convinced by her work. "Is this what we mean by teacher leadership?" I asked. We talked about how it felt like these authors had "co-opted the language of professional learning community and teacher leadership" (Meeting notes, February 13, 2013). The teachers pointed out that the authors defined teacher leadership within a hierarchical, competitive, and specific skill-based model that works within the Teach for America and Kipp systems but that did not represent the more complicated, classroom-based, collaborative view they held of the same concept.

That spring we also shared personal transitions, decisions, triumphs, and shifts in thinking, conversations that deepened our connections. For example, Maeve applied for and got a position at an elite private school. She asked us, should she leave her comprehensive public school to try something new? She was starting to feel the stress of the disheartening district conversations, of the kids' sense in her school that "no one cares" (Meeting notes, May 15, 2013). I sat back and listened with some surprise during this conversation as the other teachers in the group encouraged Maeve to take the new job, despite their firm commitment to urban public schooling. Steve Petro, an English teacher in the Philadelphia public schools, said he had taught six years in private schools and five years in public schools and that it had given him a "broad sense of what is out there. You may find that what energizes you is the content which you can engage in at a higher level. Or you may find it in the pedagogy or personal relationships with students. You won't know till you leave (what will be your eventual choice)." Others pointed out that more experienced teacher leaders to whom they had spoken in their first leadership institute had told them that you have to be strategic, to protect yourself and your well-being, in order to have a longterm commitment to teaching. Maeve was clearly energized - and relievedto hear that this cohort of teacher leaders supported her choice.

During the second year, I asked the group to brainstorm what it meant to have a teacher leadership stance as a way of thinking about how to reframe the draft of the book introduction to be more focused on teachers. Jennifer (Jenny) Lunstead's writing reflected a thread we had been work- 
ing with throughout our time together, that teachers become leaders over time, recognizing the value of their intellectual, political, and collaborative work:

\section{What If I Am Just a Teacher Forever?}

When I decided to take my first teaching job, I cried. Not tears of joy, no such thing. I accepted the job and then I sat down on the red velvet couch in the fancy parlor of the main building on campus and cried because I was afraid I had put myself on a path away from doing big, important things in the world. Away from status, away from making the most of my elite education, away from using my intellectual abilities, away from making institutional change. I was "just" going to teach. How my college girlfriend, on whose shoulder I was sniffling, refrained from slapping me across my entitled, weepy face is a mystery.

On some level, I knew that teaching was important work. My elite education had included a lot of reading on the social justice implications of teaching. My own best teachers had impacted me in powerful ways. But...

And I wasn't entirely wrong, at first. The system was very big, and I was very small. The work was exhausting, and as a result, isolating. My colleagues were not interested in my ideas, coming as they were from a novice. My administrators interpreted my eagerness as a threat. Working with students was humbling, but I was not humble. I felt like an anthropologist studying the natives - those teachers who had been teaching for 30 years - and analyzing their strange ways.

My family and community reinforced these ideas. "You should write a book about your experience," said my dad. "So, do you find this work . . . ahem . . . intellectually challenging?" my grandfather all but sneered, still hoping I would become a scientist or engineer. "I always saw you as more of an 'institution-changer' than a 'directservice provider," " said a mentor. I wanted to be an institution changer, but nobody in the institution had the least interest in my ideas.

Today I am extremely proud of what I do. When my grandfather says, "So what exactly do you do to teach kids to read?" I retrieve the 5 -inch binder bursting with pages of notes on each of my students, and I demonstrate the investigative approach that goes into diagnosing where each child is stuck in their literacy development and how to move them to the next stage. When I speak out at a faculty meeting, 
my colleagues take the time to stop by afterwards and thank me for putting my feelings into words. Because my feelings are often our feelings, and when I speak I am thinking not about me but about us.

What is the path I took from there to here?

I had to stop being an outsider to teaching and become "one of." I had to develop the stance of teacher leadership. (TWN writing [September 2013])

This piece of writing became the vignette that started the book proposal, the one that was deemed not marketable by an educational press.

In response to the many challenges TWN members faced in school year 2014-15, we shifted in the spring of 2015 to carrying out a problem of practice protocol when we met. Sometimes the teachers wrote out their problem; sometimes they just told the story. Another member of the group served as convener. In April 2015, Stacey presented a problem of practice that involved her new mentoring position. She raised questions about how to focus her mentoring when there were so many things to talk about, how to prioritize what to observe and explore with teachers. She also explored the relationship between her mentoring and her principal's teacher evaluations. Both of these issues are embedded in the article she wrote for the first part of this symposium in the spring 2016 Schools issue (Carlough 2016). In a somewhat similar problem of practice, Ben Lewis, in his new position as assistant principal, raised questions about how to get teachers on board with a mentoring process. He also explored whether he tended to focus on teachers with whom he felt comfortable and most productive rather than on those who were more recalcitrant and sometimes more in need of change and support. Jenny, also in a new administrative position, presented a problem with a particular teacher with whom she had had some difficult conversations about her work with teachers and students of color. And Jarrod Green, thinking about his movement into administration at his school, raised concerns about how to diversify his predominantly white middle-class private preschool in ways that connected the school to the local community and incorporated anti-bias work in the classroom. The conversations around these problems of practice were thoughtful, respectful, and fruitful. They moved the group into deeper reflections on their own work as teachers, teacher leaders, and administrators. These sometimes became incorporated into later writing; they sometimes led to shifts in practice; they always involved the stance that sees teacher leadership as professional, collaborative, and political. Through our collabora- 
tive processes of meeting, talking, problem solving, and supporting one another, teachers in TWN develop the insights, skills, and voice that they use as teacher leaders.

\section{Writing to Write; Writing to Lead}

At our very first meeting in October 2012, our business was largely organizational: What should we call ourselves? What did we want to do at each meeting? We brainstormed several names, but when Alison McCartney, a colleague of Kathleen's at Consitution High School, suggested Teachers Write Now, it stuck. When I recently asked teachers to reflect on how and why we had chosen that name, Maeve wrote: "I think it was Alison's brain child. And we liked it because we wanted to WRITE at every meeting, and we felt like people should talk to and listen from teachers RIGHT now and so we were WRITE now" (E-mail correspondence, February 12, 2016).

As mentioned above, I was surprised by the teachers' interest in writing at every meeting. When I wrote the grant to support the group, I had envisioned "monthly meetings of the cohort that would include invited speakers, discussion of relevant readings, training and discussion in topics such as teacher action research, mentoring, and peer evaluation. Swarthmore students in participating seminars and courses would be invited to attend these meetings" (Eldridge Grant proposal, spring 2012). I did include a writing retreat in the third year of the project, noting that, "Teachers talked about wanting to use writing to reflect on their own work and to share their work with others; they suggested that a several day retreat could make this a reality." But as we started to meet it became very clear that writing each time we met would allow teachers to use writing more effectively to reach these goals.

In May 2013, the end of our first year, we decided to have a writing retreat. Several of us met to plan our retreat, assigning the different sessions to members of the group to lead. We met for two days in a guest house at Swarthmore College. We brainstormed and wrote about teacher leadership in classrooms, schools, districts, and society. We wrote letters to one another about why the other person was a teacher leader, trying to tease out the elusive definition of teacher leadership. We developed a new conceptteacher leadership as stance - that has become the organizing principle around which the group has continued its work (see Smulyan [2016] for additional explanation of these ideas). I asked the teachers to respond to a draft of an introduction I had written for our possible book. It was a wonderful opportunity to spend time together and to write just to write.

\section{Schools, Fall 2016}


The last activity - to write just to write- has been something I learned from the group that first year. I have, for so many years, written to accomplish some concrete goal: an article, a memo, a report, a request. The teachers in this group write to write: to organize and articulate ideas, to explore thoughts, to share their insights with one another. They see the space created by TWN as one in which they can use writing to expand their experience and understanding as teachers and teacher leaders.

Informally the group has responded to prompts provided by one another. Kathleen asked the group to write to the prompt "You are a teacher leader if . . ." in order to use it for Teachers Lead Philly, the activist teacher group she had helped to start. In response to a call from the Philadelphia Notebook, we wrote about "Why I love teaching in Philly" and "What I want to change about Philly education." Several of the group sent their responses to The Notebook, and Stacey's was published ("Teachers Write about Their Love of the Profession," The Notebook, June 23, 2014). Later in the fall, in response to a writing prompt that stemmed from one teacher's experience, we wrote about a conflict we were experiencing. In February 2015, Jarrod struggled with whether or not the administrative position he had been preparing for at his school was actually going to be there for him. He asked us to write about our "ideal job" as he tried to figure out his own next steps. Steve wrote that he would like to have 20 percent of his job devoted to personally designed professional development, time when he could try out new opportunities. Kathleen talked about the flexibility of (teaching and nonteaching) hybrid positions in a school that would allow teachers to create and try out new opportunities, to coordinate ideas and people within and outside of the school.

These opportunities to write just to write, and to share that writing within the group, have provided us with the chance to deepen our own individual understanding of our work as teachers and to extend the collaboration that supports our growth as teacher leaders. It gives each of us in the group a chance to flex our voices, to hear what our ideas sound like when given a chance to solidify into sentences, and to deepen our own knowledge in the moment as we prepare to go back to our daily work as educators. It parallels the work we do with our students in that it gives us immediate practice with ideas that have unknown consequences in the future but that aim for a better future for our students and ourselves. It is both private and public, something that sustains the individual teacher and that contributes to our collaboration as a working group of teacher leaders.

TWN participants also write for others. While some of this writing would happen whether the group met or not, we know that the collaboration and 
informal writing we do contributes to our ability and willingness to engage in the more formal writing that we hope opens up our conversation to a broader audience. In 2013-14, for example, several of the teachers wrote papers for two sessions of the annual meeting of the American Educational Research Association (AERA). Their presentations included one by Stacey and Maeve (Carlough and Siu 2014) on founding a writing center and math center, respectively, and the impact of those centers on both student learning and school culture. Kathleen Melville (2014) presented her work on Teachers Lead Philly; Ben Lewis (2014) talked about the tensions inherent in being a teacher leader and an administrator, and Scott Storm (2014) shared his analysis of doing action research with his colleagues at Harvest.

In addition to presentations at AERA, more formal TWN teacher writing includes published work in Rethinking Schools, Education Week and a book by Jarrod Green (2016), I'm OK!' Building Resilience through Physical Play. And, most recently, many of the teachers have participated in drafting and publishing articles for this symposium. For all of us, writing to inform other teachers, educators, and community members about the work we do remains a central part of who we are. It is a way of communicating the ideals and practices of teacher leadership that is political, intellectual, and collaborative work and of keeping that communication grounded in the real work of classrooms and schools.

\section{Leading into the Future: Listening to the Voices of Teachers}

In addition to writing to lead, TWN has, for the past three summers, cosponsored a summer institute for 15 Philadelphia teachers, introducing them to one another and to other teacher leaders in the Philadelphia metropolitan area. This institute is modeled on the workshops on the first Ford Foundation summer institute attended by some of the TWN cohort; it is a three-day, residential, teacher-organized, and teacher-led program that aims to engage self-identified teacher leaders in exploring how collaboration, writing, and activism can support the work that they do. Each summer members of TWN lead sessions at the summer institute. For example, Jarrod has engaged the teachers in story telling and Stacey in helping them think through approaches to mentoring. I have collaborated on a session on teacher writing, and Kathleen has worked with the new teacher leaders on the possibility of becoming politically active, developing a public voice as a teacher leader. Each summer session ends with each teacher developing an action plan, a piece of writing in which they commit to some kind of leadership project and identify the people in the room who will support them in the process of carrying it out.

208 Schools, Fall 2016 
TWN, as a small community of committed teacher leaders, decided that it did not want to continue to grow in number, although we have occasionally invited new people to join the group as some have moved away. We appreciate knowing one another, having a safe space to explore the challenges of our work, and being able to find a meeting time each month that accommodates everyone's busy schedule. Through the work within the group, we support the leadership practices (and successes and problems) experienced by the group members; collaboration and writing help keep us focused and productive. The summer institutes provide us with an opportunity for a different kind of leadership. In these, we broaden our scope, engaging other teachers in exploring the ideas and experiences that have been fruitful pathways for us - collaborating, writing, acting - in developing and practicing a leadership stance. Teachers Write Now teachers may be the "small names" in the field of education rather than the "big name" educator sought by the publisher, but they are clearly the educational leaders who are making a difference.

\section{TWN: A Think Tank for Teacher Leaders}

In the spring 2016 edition of Schools and in this fall 2016 continuation of our symposium on teacher leadership, we hear from five teachers, all members of Teachers Write Now, who reflect on their work as teacher leaders. In this second part of the symposium, Maeve O'Hara Siu, a math teacher in the School District of Philadelphia, examines what her leadership has looked like in the four different school contexts in which she has taught. Jarrod Green explores his own development as a teacher leader, finding parallels between his approaches to supporting children and adults as they grow and learn.

We see this symposium as one opportunity to share our ongoing collaboration, writing, and action around teacher leadership. We also continue to meet; there are so many everyday issues in our classrooms, our schools, and our communities that we want to examine together. Questions we want to explore include: What would a job, a school, and a district look like that allow teachers to be effective leaders? How can we bring our ideas about leadership and social justice to the urban and suburban communities and public, private, and charter schools in which we teach? What are the constraints and affordances of moving into quasi-administrative teacher leadership roles in a school - department chair, mentor, colleague teacher, coach? Is it possible to move into a traditional administrative position and maintain the stance of teacher leader? What opportunities are there to develop a teacher 
leadership stance and set of actions within teacher unions? By meeting, writing, and sharing our work with others, we continue to find ways to flourish as individuals, as collaborators, and as leaders in the field of education.

\section{References}

Carlough, Stacey. 2016. "Teacher Leadership as Mentoring." Schools: Studies in Education 13 (1): 29-45.

Carlough, Stacey, and Maeve Siu. 2014. "Side by Side: Peer-Tutoring to Empower Students, Teachers, and Schools." Paper presented at the annual meeting of the American Educational Research Association, Philadelphia, PA.

Green, Jarrod. 2016. I'm OK! Building Resilience through Physical Play. St. Paul, MN: Redleaf.

Lewis, Benjamin. 2014. "Maintaining a Teacher Leadership Stance in Administration." Paper presented at the annual meeting of the American Educational Research Association, Philadelphia, PA.

Melville, Kathleen. 2014. "Teachers Lead Philly: Advancing Teacher Voice in Education Policy." Paper presented at the annual meeting of the American Educational Research Association, Philadelphia, PA.

Smulyan, Lisa. 2016. "Stepping into Their Power: The Development of a Teacher Leadership Stance." Schools: Studies in Education 13 (1): 8-28.

Storm, Scott. 2014. "Action Research as Teacher Leadership: Teacher Experience in Professional Learning Communities." Paper presented at the annual meeting of the American Educational Research Association, Philadelphia, PA. 